\title{
Life cycle inventories of roundwood production in northern Wisconsin: Inputs into an industrial forest carbon budget
}

\author{
Molly K. White*, Stith T. Gower, Douglas E. Ahl \\ University of Wisconsin, Madison, Department of Forest Ecology \& Management, 120 Russell Laboratories, \\ 1630 Linden Drive, Madison, WI 53706, USA
}

Received 23 July 2005; accepted 15 August 2005

\begin{abstract}
Carbon budgets are developed to understand ecosystem dynamics and are increasingly being used to develop global change policy. Traditionally, forest carbon budgets have focused on the biological carbon cycle; however, it is important to include the industrial forest carbon cycle as well. The overall objective of this study was to quantify the major carbon fluxes associated with the production of Wisconsin's industrial roundwood, by using life cycle inventory (LCI) methodology to produce an industrial forest carbon budget. To achieve this objective we (1) developed carbon LCIs for the harvest process for three major forest ownerships (state, national, and private non-industrial), (2) developed carbon LCIs for a dimensional lumber and two oriented strand board (OSB) mills and (3) completed a scaled version of 1 and 2 to include more Wisconsin forestlands and to incorporate the other major processes within the industrial forest carbon cycle (e.g. primary mill, secondary mill, product use and product disposal processes of the industrial forest carbon cycle). The carbon budgets for the harvesting process of the ChequamegonNicolet National Forest (CNNF), the Northern Highland American Legion State Forest (NHAL), and the non-industrial private

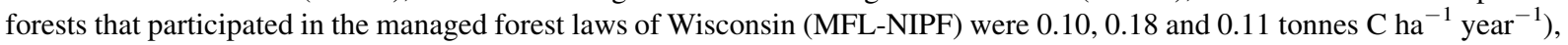
respectively. The dimensional lumber and OSB products were both net carbon sources, and released $0.05-0.09$ tonnes $\mathrm{C} /$ tonnes $\mathrm{C}$ processed). More carbon is sequestered than released within the industrial forest carbon cycle of Wisconsin's national $\left(6 \mathrm{~g} \mathrm{C} \mathrm{m}^{-2}\right.$ year $\left.^{-1}\right)$, state $\left(12 \mathrm{~g} \mathrm{C} \mathrm{m}^{-2}\right.$ year $\left.^{-1}\right)$ and non-industrial private forests $\left(7 \mathrm{~g} \mathrm{C} \mathrm{m}^{-2}\right.$ year $\left.^{-1}\right)$. Using published net ecosystem production data we estimate that the net forest carbon cycle budget (sum of the biological and industrial $\mathrm{C}$ cycle, [Gower, S.T., 2003. Patterns and mechanisms of the forest carbon cycle. Ann. Rev. Environ. Resour. 28, 169-204]) for the CNNF ranges between -897 and $348 \mathrm{~g} \mathrm{C} \mathrm{m}^{-2}$ year $^{-1}$. Life cycle inventories of wood and paper products should be clear and explicitly state what processes are included, so that results can be used by policy makers and future researchers.
\end{abstract}

(C) 2005 Elsevier B.V. All rights reserved.

Keywords: Life cycle inventory; Carbon budget; Roundwood; Wisconsin forests; Dimensional lumber; Oriented strand board

\footnotetext{
* Corresponding author. Tel.: +1 608262 6369; fax: +1 6082629922.

E-mail address: mkwhite@wisc.edu (M.K. White).
} 


\section{Introduction}

The rapid rise of atmospheric carbon dioxide $\left(\mathrm{CO}_{2}\right)$ and other greenhouse gas (GHG) concentrations will cause a variety of environmental, social and economic problems, and is therefore one of the most pressing environmental issues facing society today (IPCC, 2001). The industrial dimensions of global change: society, economy, technology, and culture, influence the ecological dimensions; conversely, the ecological dimensions of global change: land use, biodiversity, and flows of resources, influence the industrial dimensions (Vitousek et al., 1997). Carbon budgets have been developed to understand carbon cycling and ecosystem dynamics and are increasingly being used to develop climate change mitigation policy.

The forest carbon cycle is a primary focus of climate change mitigation policy. The forest carbon cycle is comprised of a biological and industrial cycle, and both should be studied in concert (Gower, 2003). The forest biological carbon budget, or net ecosystem production, is the sum of all carbon fluxes, which indicate an annual sequestration or emission of carbon. Globally, forests contain $90 \%$ of the total vegetative carbon and $80 \%$ of the soil carbon and they assimilate $67 \%$ of the total terrestrial carbon dioxide $\left(\mathrm{CO}_{2}\right)$ sequestered from the atmosphere (Landsberg and Gower, 1997). The industrial forest carbon budget is the net emission of carbon throughout forest product lifespan (i.e. cradle [tree growth] to grave [disposal]). The net carbon budget can either be positive or negative. (In this paper, a negative flux implies a net transfer of carbon to the atmosphere, and a positive flux implies a net transfer of carbon to roundwood.) The role of the industrial carbon cycle is equally as important as the biological cycle for studying climate change. The United State's carbon stock of wood products and landfilled wood products in 1997 was $3520 \times 10^{6}$ metric tonnes, an increase of $17 \%$ from 1987 (Birdsey and Lewis, 2002). Annual world consumption of paper in the mid-1990s was approximately $270 \times 10^{6}$ metric tonnes (PPI, 1996). In Wisconsin alone, $10.4 \times 10^{6} \mathrm{~m}^{3}$ of roundwood was harvested in 1999 (Reading and Whipple, 2003). Human decisions made within the industrial forest carbon cycle can mitigate or aggravate the net carbon balance of forest ecosystems (Apps et al., 1999).
The industrial forest carbon cycle involves tracking carbon emissions and accumulation through the production of a wide range of goods and services produced from forests for societal use. The industrial forest carbon cycle includes emissions from forest management (site preparation to harvesting), transport, production, consumer use and disposal operations, which all release $\mathrm{CO}_{2}$ through fossil fuel burning and energy use. The rate at which carbon stored in forest products is returned to the atmosphere is determined by consumer use and end-of-life processes (i.e. landfilling, incineration, or recycling) and creates a lag time in the carbon cycle (Karjalainen, 1996). Temporary carbon storage in wood and paper products is important because it slows down the rate of atmospheric $\mathrm{CO}_{2}$ concentrations. More importantly, forest products are critical to identifying major sources of $\mathrm{CO}_{2}$ emissions and developing policies to reduce carbon emissions. A major impediment to reducing $\mathrm{CO}_{2}$ emissions is that the industrial forest carbon cycle spans many sectors (i.e. energy, transportation and waste management) and as a result is very complex.

The division of management within the forest carbon cycle, and how the roles of those management choices affect carbon sequestration and emission, is critical to developing a comprehensive carbon management program. The varying sectors, including forest land owners, forest product mill managers, forest product business owners, energy, transportation, consumers, governments and non-governmental organizations, all have stakes in proposed climate mitigation policy. Under some policies, for example, it will be important to understand ownership roles, so sequestered carbon credit and debt can be allocated appropriately (Miner and Lucier, 2003). A disaggregated scale of analysis is required for studying forest carbon budgets in the United States because of the existence of diverse forest ecotypes, ownerships and companies (Birdsey and Lewis, 2002).

Life cycle assessment (LCA) based methodologies are industrial ecology tools that can be used to evaluate the environmental effects of a product, process, or activity (Curran, 1996). The Society of Environmental Toxicology and Chemistry (SETAC) has defined the components of LCA to include a goal and scoping definition, inventory step, and an impact/ improvement assessment (Consoli et al., 1993). Life cycle inventory (LCI), a LCA based methodology, 
includes a goal and scoping definition and an inventory step. LCI can elucidate what processes are included and excluded from an analysis of an industrial forest carbon budget. LCI can also provide a framework for critique and comparison among other carbon budget studies.

Within the forest sector, LCI methodologies have been used to determine environmental and economic costs/benefits of forest products when compared to non-forest product alternatives (Ueda et al., 2003; Petersen and Solberg, 2005), to quantify energy use and emissions from harvest machinery production (Athanassiadis et al., 2002), to compare environmental impacts of producing forest products from different regions (Berg, 1997; Seppala et al., 1998), and to locate processes within forest product production that could be improved to reduce environmental burdens (Forsberg, 2000; Schlosser et al., 2003; Gower et al., in preparation).

The objectives of this study were to: (1) develop carbon LCIs of the forest harvesting process (LCI-H) for three forest ownerships, (2) develop carbon LCIs for the primary mill process (LCI-PM) for a dimensional lumber and two oriented strand board (OSB) mills and (3) use data from objectives 1 and 2, and other relevant studies to estimate the industrial forest carbon budget for the national, state and non-industrial private forests of Wisconsin. Objective 1 provided needed data to answer the question, "Are $\mathrm{CO}_{2}$ emissions from harvesting similar for state, federal, and non-industrial private forests?'. Objective 2 increased carbon LCI data for other wood and paper products (see Gower et al., in preparation). Results from the above objectives were used to (i) identify key industrial forest processes that could be modified to mitigate carbon emissions to the atmosphere and/or increase carbon sequestration, and (ii) couple the industrial forest carbon budget with a biological forest carbon budget to create a 'complete' forest carbon budget.

\section{Methodology}

\subsection{LCI boundaries and general case study approach}

The national, state and non-industrial forest lands comprise $71 \%$ of the 16 million acres of forested land in Wisconsin. The Chequamegon Nicolet National Forest (CNNF) and the Northern Highland American Legion (NHAL) State Forest are both located in northern Wisconsin. The non-industrial private forests that are enrolled in the managed forest laws of Wisconsin (MFL-NIPFs) are located throughout the state. The forests in northern Wisconsin are characterized by gently rolling terrain, a short growing season and long cold winters. The landscape includes pitted outwash plains, kettle lakes, extensive forests and wetlands. Common forest ecosystems in northern Wisconsin include hemlock/hardwood, white and red pine with smaller pockets of jack pine, aspen/birch occurring in openings formed by disturbance events, and spruce/fir.

For the purposes of this study we divided the industrial forest carbon cycle into six processes: (1) pre-harvest forest management, (2) harvest, (3) primary mill, (4) secondary mill, (5) product use and (6) product disposal (Fig. 1). The process boundaries were set by locating divisions of forest and forest product management for northern Wisconsin. These divisions exist because data are not routinely exchanged from one management process to the next, and so change in management was analyzed as a single process. Timber is first managed by a forest land owner (national, state, non-industrial private, city, county, tribal or industrial private). The merchantable stem (roundwood) is harvested by a purchasing company, transported by truck or rail, and processed by a primary milling company. The product is transported to a secondary milling company, distribution warehouse and/or to the consumer. The consumer uses the product until it is incinerated, landfilled or recycled.

The system boundaries of this study include the harvesting of roundwood, machinery use during harvest, transportation of roundwood to primary and secondary mills, machinery use during primary and secondary mill processing, transportation of product to distribution center, proportion of product put to end of use per year and product disposal. This study does not include pre harvest site management of forests, transportation of secondary product to consumer and transportation of product to disposal method. The LCI-H (harvesting) and LCI-PM (primary mill) include years 2000-2003, while the industrial forest carbon budget incorporated 1994-2003. The spatial 


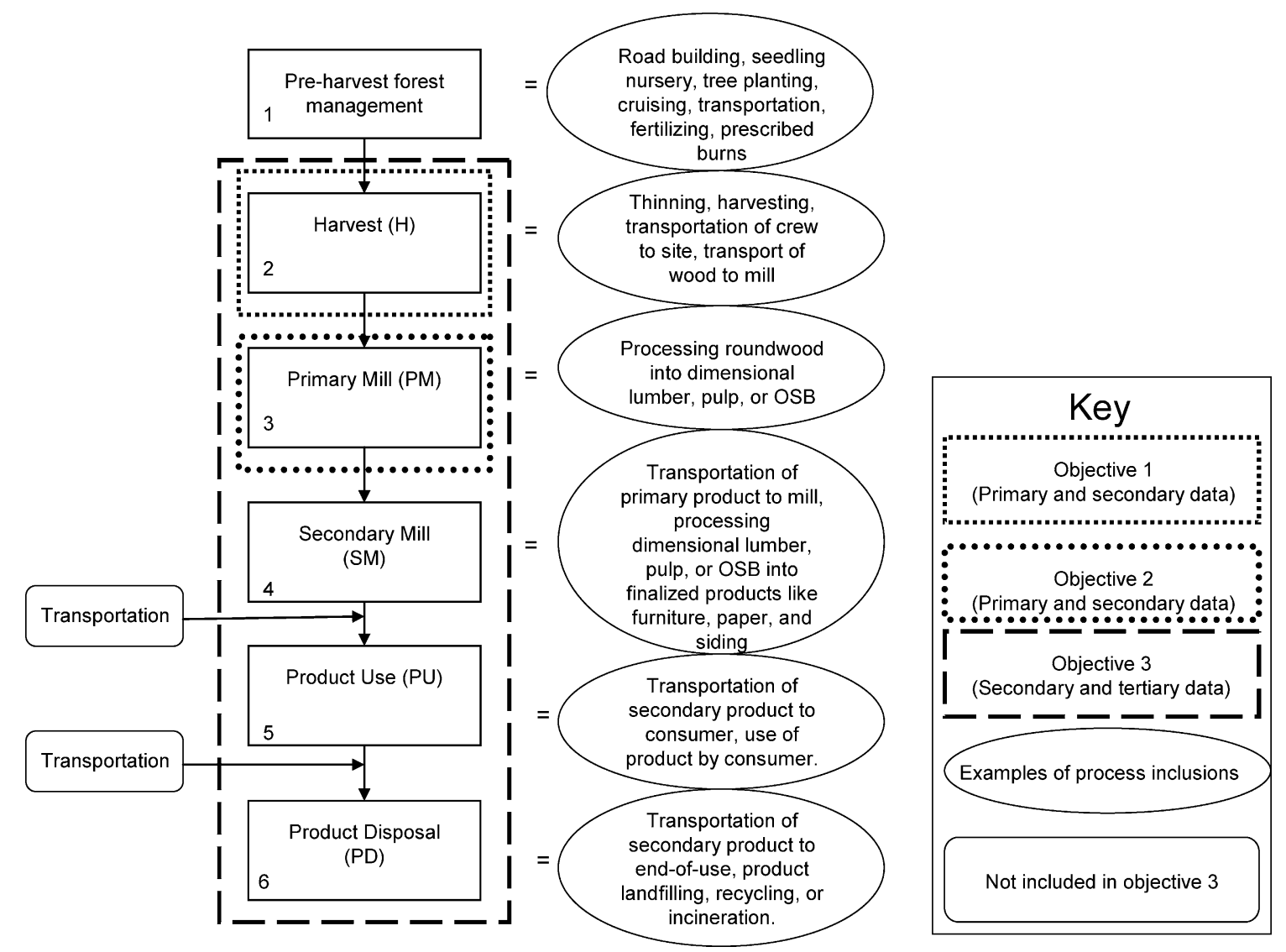

Fig. 1. A conceptual diagram illustrating the links between the six industrial forest processes. Processes are numbered and depicted in rectangles. Corresponding examples of activities within each process are depicted in ovals. This figure also highlights the level of analysis of the objectives. The LCI-H and LCI-PM, or objectives 1 and 2, were completed using primary and secondary data. Objective 3, or the industrial forest carbon budget incorporates the SM, PU, and PD processes by scaling the LCI-H and LCI-PM to the total acreage of ownership type and by incorporating tertiary data. The boundaries of investigation do not include preharvest forest management, transportation between SM and PU and $\mathrm{PU}$ and $\mathrm{PD}$, nor environmental factors other than $\mathrm{CO}_{2}$ emissions or carbon sequestrations.

boundaries for the LCI-H (objective 1) are the forests of the CNNF, NHAL, and MFL-NIPF (Table 1). The areas used to normalize the carbon budgets among forest ownership types are the total areas of forest, not the actual harvested area. The spatial boundaries for the LCI-PM (objective 2) are the mill facilities of two OSB mills and a dimensional lumber mill (Table 2). The spatial boundaries for the industrial forest carbon budget (objective 3 ) include the same boundaries as objectives 1 and 2, but also include all other national, state and NIPF forest lands in Wisconsin. Carbon emissions from transportation of roundwood and product into and out of the spatial boundary are included in all three objectives.
Objectives 1 and 2, the LCI-H and LCI-PM, were calculated using primary and secondary data. The third objective, scales the results from the LCI-H and LCI-PM, and incorporates the secondary mill, product use and product disposal processes by utilizing secondary and tertiary data to calculate the industrial forest carbon budget (Fig. 1).

The functional unit of this study is carbon (C), expressed in metric tonnes. Carbon amounts were quantified by tracking $\mathrm{CO}_{2}$ emissions to the atmosphere and carbon sequestration within each industrial forest process. Other greenhouse gas emissions, such as methane $\left(\mathrm{CH}_{4}\right)$ and nitrous oxide $\left(\mathrm{NO}_{2}\right)$ were not included. In a similar study, the contribution of $\mathrm{CH}_{4}$ 
Table 1

Forest land ownership characteristics and LCI-H results for years 2000-2003 (data are reported as averages of the four years)

\begin{tabular}{|c|c|c|c|}
\hline & \multicolumn{3}{|c|}{ Forest land ownerships } \\
\hline & CNNF & NHAL & MFL-NIPF \\
\hline Total area (ha) & 607028 & 89840 & 1011714 \\
\hline Area harvested (ha) ${ }^{\mathrm{a}}$ & $5823(1182)$ & $581(341)$ & - \\
\hline Ownership & National (USFS) & State (WI DNR) & Non-industrial private owner \\
\hline $\begin{array}{l}\text { Fraction of total ownership type case } \\
\text { tudy represents in WI (\%) }\end{array}$ & 94 & 45 & 27 \\
\hline $\mathrm{C}$ in harvest (tonnes) ${ }^{\mathrm{a}}$ & $99880(21940)$ & $19270(9170)$ & $147980(49980)$ \\
\hline $\mathrm{C}$ exported from WI (tonnes) ${ }^{\mathrm{a}}$ & $-27470(6034)$ & $-1570(753)$ & $-26640(8997)$ \\
\hline $\mathrm{C}$ emitted (tonnes) ${ }^{\mathrm{a}}$ & $-8990(1973)$ & $-1740(865)$ & $-11750(3968)$ \\
\hline $\mathrm{C}$ emitted (tonnes): $\mathrm{C}$ harvested (tonnes): $\bar{x}$ & -0.09 & -0.09 & -0.08 \\
\hline LCI-H C budget (tonnes $\mathrm{C} \mathrm{ha}^{-1}$ year $\left.^{-1}\right)^{\mathrm{a}}$ & $0.10(0.02)$ & $0.18(0.08)$ & $0.11(0.04)$ \\
\hline
\end{tabular}

${ }^{\mathrm{a}}$ Expressed as: $\bar{x} \pm 1$ (S.D.).

and $\mathrm{NO}_{2}$ comprised less than $1 \%$ of the total $\mathrm{CO}_{2}$ equivalents for dimensional lumber and two magazines (Gower et al., in preparation).

The LCIs were conducted using methodology outlined in Society of Environmental Toxicology and Chemistry (SETAC) (De Beaufort-Langeveld et al., 2003) and follows the International Standards Organization (ISO) LCA 14041 document (1998). The inventory approach used in this study is similar to the third method described by Miner and Lucier (2003) for analyzing carbon sequestration in harvested wood products.

A cautionary note is warranted for the methods used in this study. Our analyses do not take into account total existing stocks of product, but rather focused on roundwood products being produced from years 2000 to 2003 .

\subsection{Objective 1: LCI-H of three forest ownerships}

The LCI-H data was based on 4 years (20002003) for the NHAL and the MFL-NIPF, and 3 years (2001-2003) for the CNNF. The LCI-H was calculated by quantifying the carbon content of the volumes of roundwood harvested, time harvest machinery was in use, fuel economy of machinery, roundtrip distance purchasers traveled to site, volumes of roundwood exported from state, and roundtrip distance truckers hauled wood from the site to the mill (Table 3).

Table 2

Primary mill characteristics and LCI-PM results for 2000-2003

\begin{tabular}{|c|c|c|c|c|c|}
\hline & \multicolumn{3}{|c|}{ Primary mill case study } & \multicolumn{2}{|c|}{$\begin{array}{l}\text { Primary mills from Gower et al. } \\
\text { (in preparation) }\end{array}$} \\
\hline & OSB mill A & OSB LPT & DL & Pulp & Chetwynd DL \\
\hline Predominant species processed & Aspen & Aspen & Red, white pine & Aspen & $(-)$ \\
\hline Product purchased & Pulpwood & Pulpwood & Sawlogs & Pulpwood, chips & Sawlogs \\
\hline Materials sold & OSB, bark & OSB, bark, fines & Lumber, chips, shavings, bark & Pulp & $(-)$ \\
\hline $\mathrm{C}$ processed (tonnes) ${ }^{\mathrm{a}}$ & $369959(32100)$ & $54665(4250)$ & $10962(666)$ & $396800(-)$ & $96585(-)$ \\
\hline $\mathrm{C}$ emitted (tonnes) ${ }^{\mathrm{a}}$ & $-19170(850)$ & $-5520(120)$ & $-567(-)$ & $-20750(-)$ & $-2469(-)$ \\
\hline $\begin{array}{l}\text { LCI-PM C budget } \\
\quad(\text { tonnes C:tonnes C processed) }\end{array}$ & $-0.05(0.005)$ & $-0.09(0.005)$ & $-0.05(0.003)$ & $-0.05(-)$ & $-0.03(-)$ \\
\hline $\begin{array}{l}\text { Expanded LCI-PM C budget } \\
\text { (tonnes C:tonnes C processed) } \\
\text { to include transportation }^{\mathrm{a}}\end{array}$ & $-0.113(0.005)$ & $-0.116(0.005)$ & $-0.079(0.024)$ & $-(-)$ & $-0.627(-)$ \\
\hline
\end{tabular}

\footnotetext{
${ }^{\mathrm{a}}$ Expressed as: $\bar{x} \pm 1$ (S.D.).
} 
Table 3

Parameters used to calculate LCI-H

\begin{tabular}{|c|c|c|c|c|}
\hline Parameter & $\begin{array}{l}\text { Example parameter } \\
\text { value }\end{array}$ & $\begin{array}{l}\text { Vary acrossed } \\
\text { ownership }\end{array}$ & $\begin{array}{l}\text { Data } \\
\text { type }\end{array}$ & $\begin{array}{l}\text { Reference or } \\
\text { data source }^{\mathrm{a}}\end{array}$ \\
\hline Harvest volume $\left(\mathrm{m}^{3}\right)$ & 525148 & $\mathrm{Y}$ & $\mathrm{P}$ & (7), (9) \\
\hline Softwood and hardwood harvest volume $\left(\mathrm{m}^{3}\right)$ & 262553 & $\mathrm{Y}$ & $\mathrm{S}$ & (1) \\
\hline Time machinery is in use to harvest $200 \mathrm{~m}^{-3}(\mathrm{~h})$ & 56.69 & $\mathrm{~N}$ & $\mathrm{P}$ & (10) \\
\hline Roundtrip distance to site $(\mathrm{km})$ & 107 & $\mathrm{Y}$ & $\mathrm{P}$ & (10) \\
\hline Ratio of exported roundwood & 0.28 & $\mathrm{Y}$ & $\mathrm{P}$ & (10) \\
\hline Area of case study (ha) & 607028 & $\mathrm{Y}$ & $\mathrm{P}$ & (9) \\
\hline Carbon in harvest volume $\left(\mathrm{kg} \mathrm{m}^{-3}\right)$ & 203 & $\mathrm{~N}$ & $\mathrm{~S}$ & $(2),(8)$ \\
\hline Harvester fuel economy $\left(1 \mathrm{~h}^{-1}\right)$ & 19 & $\mathrm{~N}$ & $\mathrm{~S}$ & (4) \\
\hline Forwarder fuel economy $\left(1 \mathrm{~h}^{-1}\right)$ & 11 & $\mathrm{~N}$ & $\mathrm{~S}$ & (4) \\
\hline Chainsaw fuel economy $\left(\mathrm{h} \mathrm{h}^{-1}\right)$ & 0.47 & $\mathrm{~N}$ & $\mathrm{~S}$ & (10) \\
\hline Ratio of mechanized harvesting & 0.86 & $\mathrm{Y}$ & $\mathrm{P}$ & (6) \\
\hline Carbon in combusted diesel $\left(\mathrm{kg} \mathrm{l}^{-1}\right)$ & 0.83 & $\mathrm{~N}$ & $\mathrm{~S}$ & (3) \\
\hline Fuel economy of diesel truck $\left(\mathrm{km} \mathrm{l}^{-1}\right)$ & 8 & $\mathrm{~N}$ & S & (5) \\
\hline Load per logging truck $\left(\mathrm{m}^{3}\right)$ & 24 & $\mathrm{~N}$ & $\mathrm{~S}$ & (3) \\
\hline Fuel economy of diesel logging truck $\left(\mathrm{km} \mathrm{l}^{-1}\right)$ & 2.6 & $\mathrm{~N}$ & $\mathrm{~S}$ & (3) \\
\hline Time worked per day (h) & 8 & $\mathrm{~N}$ & S & (1) \\
\hline Distance from forest to mill $(\mathrm{km})$ & 105 & $\mathrm{~N}$ & $\mathrm{P}$ & $(10)$ \\
\hline
\end{tabular}

Yes $(\mathrm{Y})$ and no $(\mathrm{N})$ indicate whether values for respective parameters varied across forest ownerships. Primary $(\mathrm{P})$ indicates the value is collected data. Secondary $(\mathrm{S})$ indicates value is assumed based on a primary reference or is an averaged value of collected data.

${ }^{\text {a }}$ Reference or data source: (1) assumptions: (i) harvest is half softwood and half hardwood, except in the case of NHAL where actual (P) data were available. (ii) Standard workday in the U.S. is 8 h; (2) Birdsey and Lewis (2002); (3) Gower et al. (in preparation); (4) data: Harvester and forwarder company, personal communication (2004); (5) heavy duty truck company websites (2003); (6) Rickenbach and Steele (in preparation); (7) data: USDA Forest Service (2003); (8) Skog and Nicholson (1998); (9) data: Wisconsin Department of Natural Resources (2003); (10) White (2005).

Data from timber sales, cutting reports and law records were used to calculate total roundwood harvested. Quantities of carbon in roundwood were calculated using ratios reported in Birdsey and Lewis (2002) for north central species. Values for the NHAL and CNNF ownership for harvested roundwood exports, harvest machinery use, harvest machinery fuel economies, logger transportation to forest site and time required to harvest were based on 18 purchaser questionnaire responses (White, 2005). Values for the ratio of mechanized (harvester, forwarder, chainsaw) versus non-mechanized (chainsaw) harvesting practices were applied to each forest ownership (Rickenbach and Steele, in preparation). Ratios for harvesting practices and roundwood exports on MFL-NIPF lands were assumed to be the same as those on the CNNF and the NHAL. Values for logging truck loads, fuel economies of logging trucks and carbon contents of diesel fuel were standard Environmental Protection Agency values used by Gower et al. (in preparation). Fuel economies reported on company websites were used for heavy duty truck passenger vehicles. Exports of wood from the state were considered a net carbon loss (e.g. Winjum et al., 1998). The area of the forest land ownerships were used to normalize carbon budgets among forest ownerships.

The LCI-H carbon budgets were calculated by quantifying the carbon harvested $\left(H_{\mathrm{H}}\right)$, plus the carbon exported $\left(X_{\mathrm{H}}\right)$ from Wisconsin, plus the carbon associated with $\mathrm{CO}_{2}$ emissions to the atmosphere $\left(E_{\mathrm{H}}\right)$, and dividing by the total area of the case study forest ownership, shown in Eq. (1).

LCI-H $\mathrm{C}_{\text {budget }}=\frac{H_{\mathrm{H}}+X_{\mathrm{H}}+E_{\mathrm{H}}}{\text { Area }}$

\subsection{Objective 2: LCI-PM of three primary mills}

The LCI-PM was calculated for 4 years (20002003) for a dimensional lumber mill and two OSB mills. The LCI-PM was calculated by quantifying the carbon associated with fuel and electricity use of roundwood processing. Dimensional lumber was considered to be boards from 0.05 to $0.13 \mathrm{~m} \mathrm{(2-}$ 5 in.) thick and 0.05 or more meters wide and OSB as 
Table 4

Parameters used to calculate LCI-PM

\begin{tabular}{|c|c|c|c|c|}
\hline Parameter & $\begin{array}{l}\text { Example parameter } \\
\text { value }\end{array}$ & $\begin{array}{l}\text { Vary acrossed } \\
\text { ownership }\end{array}$ & $\begin{array}{l}\text { Data } \\
\text { type }\end{array}$ & $\begin{array}{l}\text { Reference or } \\
\text { data source }{ }^{\mathrm{a}}\end{array}$ \\
\hline Roundwood volume processed (tonnes) & 703826 & $\mathrm{Y}$ & $\mathrm{P}$ & (4) \\
\hline Softwood and hardwood volume processed (tonnes) & 24342 & $\mathrm{Y}$ & $\mathrm{P}$ & (1), (4) \\
\hline Imported roundwood volume processed (tonnes) & 154815 & $\mathrm{Y}$ & $\mathrm{P}$ & $(1),(4)$ \\
\hline Natural gas (therms) & 3000048 & $\mathrm{Y}$ & $\mathrm{P}$ & $(1),(4)$ \\
\hline $\mathrm{CO}_{2}$-equivalents per $(\mathrm{GJ})$ of natural gas $(\mathrm{kg})$ & 55.96 & $\mathrm{~N}$ & $\mathrm{~S}$ & (6), (7), (8) \\
\hline Propane (1) & 333631 & Y & $\mathrm{P}$ & $(1),(4)$ \\
\hline (BTU)s in 1 gallon of propane (btu) & 95475 & $\mathrm{~N}$ & $\mathrm{~S}$ & (3) \\
\hline $\mathrm{CO}_{2}$-equivalents per $(\mathrm{GJ})$ of propane $(\mathrm{kg})$ & 62.99 & $\mathrm{~N}$ & $\mathrm{~S}$ & (6), (7), (8) \\
\hline Fuel oil (l) & 1458690 & $\mathrm{Y}$ & $\mathrm{P}$ & $(1),(4)$ \\
\hline (BTU)s in 1 gallon of middle distillate fuel oil (btu) & 138690 & $\mathrm{~N}$ & $\mathrm{~S}$ & (5) \\
\hline $\mathrm{CO}_{2}$-equivalents per $(\mathrm{GJ})$ of fuel oil $(\mathrm{kg})$ & 73.53 & $\mathrm{~N}$ & $\mathrm{~S}$ & $(6),(7),(8)$ \\
\hline Electricity $(\mathrm{kWh})$ & 65675812 & $\mathrm{Y}$ & $\mathrm{P}$ & $(1),(4)$ \\
\hline $\mathrm{CO}_{2}$ per $(\mathrm{MWh})$ of electricity in Wisconsin $(\mathrm{kg})$ & 798.62 & $\mathrm{~N}$ & $\mathrm{~S}$ & (2) \\
\hline
\end{tabular}

Yes $(\mathrm{Y})$ and no $(\mathrm{N})$ indicate whether values for respective parameters varied across forest ownerships. Primary $(\mathrm{P})$ indicates the value is collected data. Secondary (S) indicates value is assumed based on primary reference or is an averaged value of collected data.

${ }^{a}$ Reference or data source: (1) assumptions: (i) If not reported, OSB chips are all hardwood. (ii) If not reported, imports and exports do not exist at mill. (iii) If fuel/electricity use is not reported, then no use exists at mill; (2) EPA (2004); (3) Gower et al. (in preparation); (4) data: Mills (2000-2003); (5) Wisconsin energy statistics (2003); (6) WRI et al. (2001); (7) NAFA (2004); (8) DOA (2003).

structural panels made of narrow strands of fiber oriented lengthwise and crosswise with resin binder (Evans, 2000).

Mill processing, fuel use, transportation, imported roundwood and product data were provided by a mill manager at each mill. $\mathrm{CO}_{2}$ emissions from combusted fuels were calculated using standard values published by the World Resource Institute (WRI, 2001), the Wisconsin energy statistics (DOA, 2003), and the National Association of Fleet Administrators (NAFA, 2004). $\mathrm{CO}_{2}$ emissions from electricity use were calculated using Wisconsin's state average annual output emission rate for 2000 (EPA, 2004) (Table 4).

The LCI-PM carbon budgets were calculated by quantifying carbon associated with $\mathrm{CO}_{2}$ emissions to the atmosphere $\left(E_{\mathrm{PM}}\right)$ from fuel and electricity use, and divided by the carbon processed $\left(P_{\mathrm{PM}}\right)$ at each case study mill, shown in Eq. (2).

LCI-PM C budget $=\frac{E_{\mathrm{PM}}}{P_{\mathrm{PM}}}$

A model analysis was conducted to scale the LCIPM to include transportation of roundwood to the mill facility and product to the secondary mill facility. Parameters used for this simulation were similar to those used for the LCI-PM. This simulation was completed to compare the dimensional lumber and
OSB products of this study with other forest product LCIs.

\subsection{Objective 3: industrial forest carbon budget}

The industrial forest carbon cycle calculation introduces tertiary data for secondary mill, product use and product disposal processes. These data require the use of many assumptions (Table 5).

The calculation scales the forest ownerships of the LCI-H up to total area of ownership type in Wisconsin. The industrial forest carbon budget for each forest ownership type $\left(\mathrm{C}_{\text {budget }}\right)$ was calculated by adding the product of the LCI-H carbon budget (LCI-H C $\mathrm{budget}_{\text {) }}$ ) and total area $\left(\right.$ Area $\left._{\text {total }}\right)$, plus the product of the LCIPM carbon budget (LCI-PM $\mathrm{C}_{\text {budget }}$ ) and total roundwood harvested $\left(H_{\text {total }}\right)$, plus the carbon budget of the secondary mill and product disposal processing (SM\&PD $\mathrm{C}_{\text {budget }}$ ) of total roundwood harvested $\left(H_{\text {total }}\right)$, divided by the total area $\left(\right.$ Area $\left._{\text {total }}\right)$, as shown in Eq. (3).

$$
\begin{aligned}
& \text { (LCI-H C } \left.\text { budget } \times \text { Area }_{\text {total }}\right) \\
& +\left(\text { LCI-PM C } C_{\text {budget }} \times H_{\text {total }}\right) \\
& \mathrm{C}_{\text {budget }}=\frac{+\left(\mathrm{SM} \& \mathrm{PDC} \mathrm{C}_{\text {budget }} \times H_{\text {total }}\right)}{\text { Area }_{\text {total }}}
\end{aligned}
$$


Table 5

Assumptions used to calculate the industrial forest carbon budget

\begin{tabular}{|c|c|}
\hline Assumption number & Assumption \\
\hline 1 & $\begin{array}{l}\text { The same type of harvesting that occurred in the LCI-H case studies is } \\
\text { occurring on all acreage of that ownership type in WI }\end{array}$ \\
\hline 2 & $\begin{array}{l}\text { Ratios Rickenbach and Steele (in preparation) tabulated for } \\
\text { the northwest and northeast units of WI are representative for the entire state and that } \\
\text { each forest ownership type has the same ratios }\end{array}$ \\
\hline 3 & $\begin{array}{l}\text { Ratios for roundwood to mill type are } 0.74=\text { pulp/paper, } \\
0.13=\text { large saw mill, } 0.1=\text { small saw mill }\end{array}$ \\
\hline 4 & Three types of primary mill's carbon budgets in the LCI-PM represent all in WI \\
\hline 5 & OSB mill A, OSB LPT, and pulp are representative for all pulp/paper mills in WI \\
\hline 6 & Dimensional lumber mill is a representative large saw mill for WI \\
\hline 7 & Dimensional lumber mill is a representative small saw mill for WI \\
\hline 8 & There are only pulp/paper, large saw, and small saw mill types in WI \\
\hline 9 & Secondary products weigh twice that of how much carbon is used to make them \\
\hline 10 & All pulp/paper mill products are made into magazines \\
\hline 11 & All large and small saw mill products are made into dimensional lumber based products \\
\hline 12 & $\begin{array}{l}\text { The case studies within Gower et al. (in preparation) contain } \\
\text { representative secondary mill processing for all secondary mill processing in WI }\end{array}$ \\
\hline 13 & $\begin{array}{l}\text { The carbon budgets for secondary products are }(0.57 \text { tonnes } C / \text { tonnes of magazine }) \text {, } \\
\text { ( } 0.61 \text { tonnes } C / \text { tonnes of magazine }),(0.22 \text { tonnes } C / \text { tonnes of DL product })\end{array}$ \\
\hline 14 & $\begin{array}{l}\text { Secondary mill processing makes up } 7 \% \text { of the } \mathrm{C} \text { budget for magazines, which } \\
\text { includes: transport of paper to printers, magazine printing, and distribution of magazine }\end{array}$ \\
\hline 15 & $\begin{array}{l}\text { Secondary mill processing makes up } 94 \% \text { of the } \mathrm{C} \text { budget for dimensional lumber, } \\
\text { which includes: transportation of dimensional lumber to distribution centers }\end{array}$ \\
\hline 16 & $\begin{array}{l}\text { Proportion of pulp/paper mill production goes into respective half-life's } \\
\text { of } 1 \text { year: } 0.75 \text { and } 20 \text { year: } 0.25 \text { and } 50 \text { year: } 0\end{array}$ \\
\hline 17 & $\begin{array}{l}\text { Proportion of large and small saw mill production goes into respective } \\
\text { half life's of } 1 \text { year: } 0 \text { and } 20 \text { year: } 0.25 \text { and } 50 \text { year: } 0.75\end{array}$ \\
\hline 18 & $\begin{array}{l}\text { Products decay according to the decay curve used in the Miner } \\
\text { (submitted, 2004) } 100 \text { year method }\end{array}$ \\
\hline 19 & 75 years for half life snapshot calculation \\
\hline 20 & 1 and 20 year products are disposed of according to the WI MSW report of 2000 (2003) \\
\hline 21 & 50 year products are disposed of in the same way as 20 year products \\
\hline 22 & $\begin{array}{l}\text { Ratios calculated from Denison (1996) of (tonnes) of } \mathrm{CO}_{2} \text { emitted per } \\
\text { (tonnes) of carbon in product disposed of are the same for Wisconsin forest products }\end{array}$ \\
\hline
\end{tabular}

Carbon emissions per tonne of secondary mill production for magazines and dimensional lumber were used from Gower et al. (in preparation) to develop the carbon budget for the secondary mill. For the purposes of this study, secondary mill emissions include secondary mill processing, the transportation between mills and distribution warehouses, and further product assembly operations. Products from paper mills were assumed to go into products with one and 20 year half lives (the time after which half the carbon placed in use is no longer in use) with a ratio of $3: 1$. Products from large and small saw mills were assumed to go into products with 20 and 50 year half lives with a ratio of 1:3. Half life values were derived from Skog and Nicholson (1998).
The product use phase neither sequesters nor emits carbon; it serves only as a lag time. This lag time does not factor into a 'snap shot' carbon budget calculation. The product use phase was determined for 1 year, and thus this 'snap shot' assumed products carried a fraction of original carbon production left after 75 years. This fraction was derived according to the 100 year method (Miner, in press). Product disposal types were 3 end-of-uses; landfilled, recycled and incinerated. Ratios for dividing 1 year and 20 year products into product disposal types were estimated using the Wisconsin trash tally (WI DNR 2003). Ratios for dividing 50 year products into product disposal types were assumed to have the same ratios as 20 year products. $\mathrm{CO}_{2}$ emitted per tonnes of product in 
product disposal types were estimated from an emissions table that Denison (1996) reproduced from a 1994 Franklin Associates municipal solid waste study.

\subsection{Data quality and sensitivity analysis}

Data quality was assessed by documenting it as primary, secondary or tertiary. Franklin Associated, Ltd. has suggested assigning data quality indicators (DQI) to data sets (Kusko and Hunt, 1997). For this study, primary and secondary data carry DQIs of 5 or 4, and tertiary data are those that carry DQIs of 3,2 or 1. Tertiary data are consistent with assumptions used in other LCI studies. The documentation of data quality and parameter sensitivity within each model increases the transparency of methods and confidence in results.

All parameters within the LCIs were tested for sensitivity by individually increasing and decreasing them by $10 \%$ (e.g. Winjum et al., 1998). The impact on the carbon budget was assessed by calculating the percent change of output. The higher the percent change of output, the more sensitive the model is to that parameter. Conversion factors were not considered parameters for the purposes of the sensitivity analysis.

\section{Results}

\subsection{Objective 1: LCI-H of three forest ownerships}

The average annual harvesting carbon budgets were $0.10,0.18$ and 0.11 tonnes $\mathrm{C} \mathrm{ha}^{-1}$ year $^{-1}$ for the CNNF, NHAL and MFL-NIPF, respectively (Table 1). The interannual variability of harvested roundwood volumes was 31, 26 and 59\% for the CNNF, NHAL and MFL-NIPF, respectively. The greatest volume of roundwood was harvested in 2001 while the smallest volume was harvested in 2000. In all years the MFLNIPF harvested the most roundwood, followed by CNNF, and NHAL. However, NHAL harvested more on a per hectare basis, followed by MFL-NIPF and the CNNF. The amounts of roundwood exported from the state were within 3\% for the CNNF and MFL-NIPF land ownership, while the NHAL exported $94 \%$ less than the MFL-NIPF. The ratio between carbon emitted to the atmosphere and carbon sequestered in harvest differed by less than $12 \%$ among the three forest land ownerships.

\subsection{Objective 2: LCI-PM of three primary mills}

The average primary mill carbon budgets for the OSB mill A, OSB Louisiana Pacific Tomahawk mill (LPT), and Pukall dimensional lumber mill were $-0.051,-0.137$ and -0.052 tonnes $\mathrm{C} /$ tonnes $\mathrm{C}$ processed, respectively (Table 1). The amount of carbon processed decreased from the OSB mill A $\left(278.6 \times 10^{3}\right.$ tonnes C) $>$ OSB LPT $\left(40.6 \times 10^{3}\right.$ tontonnes $\mathrm{C})>$ to Pukall dimensional lumber mill $\left(10.9 \times 10^{3}\right.$ tonnes $\left.\mathrm{C}\right)$. Absolute carbon emitted to the atmosphere from pulp mill processing (Gower et al., in preparation) was $97 \%$ greater than dimensional lumber mill processing, followed by both OSB mills with 8 and $73 \%$.

Inclusion of transportation (an expansion of LCIPM boundaries) increased net carbon emissions for the products by $25-55 \%$, with total carbon emissions of $-0.078,-0.113$ and -0.173 tonnes $\mathrm{C} /$ tonnes $\mathrm{C}$ processed for Pukall dimensional lumber mill, OSB mill A and OSB LPT, respectively (Fig. 2).

\subsection{Objective 3: industrial forest carbon budget}

The industrial forest carbon budget was $6 \mathrm{gC}$ $\mathrm{m}^{-2}$ year $^{-1}$ for the National forests, $-12 \mathrm{~g} \mathrm{C} \mathrm{m}^{-2}$

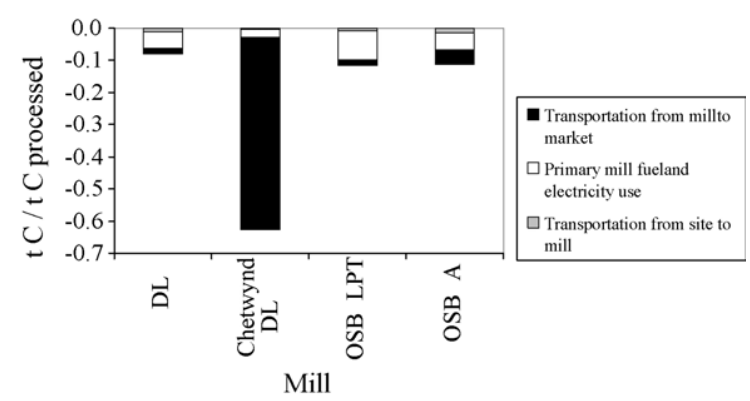

Fig. 2. Summary of the primary mill carbon budget, or the ratio of carbon emissions to carbon processed at each mill. The LCI-PM is represented in white, and the expanded LCI-PM to include transportation is represented by gray, white and black. For comparison, data from the Chetwynd dimensional lumber LCI (Gower et al., in preparation) were included. Negative values indicate carbon sources (i.e. emission to the atmosphere). 


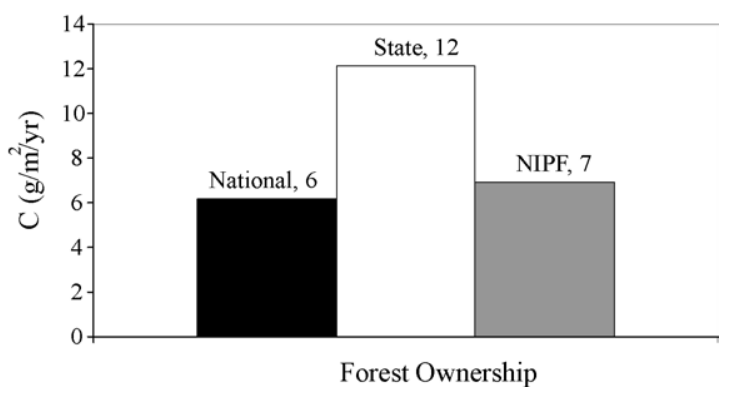

Fig. 3. The industrial forest carbon budgets for the national, state, and NIPF forested lands in Wisconsin. Positive values indicate carbon sinks (i.e. sequestration the atmosphere).

year $^{-1}$ for the State forests and $7 \mathrm{~g} \mathrm{C} \mathrm{m}^{-2}$ year $^{-1}$ for the NIPF (Fig. 3).

Combining the industrial forest carbon budgets for the three ownership types produced an overall budget of $7 \mathrm{~g} \mathrm{C} \mathrm{m}^{-2}$ year $^{-1}$. The largest component to the combined industrial forest carbon budget was the NIPF harvest process $(60 \%)$. The next largest components were the national $(8 \%)$ and state $(7 \%)$ harvest processes, the pulp and large saw product (6\%) secondary mill processes, and the pulp mill primary process (5\%) (Fig. 4). Within the product use process, amounts of carbon processed were greatest in the NIPF land ownership $\left(701 \times 10^{3}\right.$ tonnes $\left.C\right)$ and 1 year products $\left(487 \times 10^{3}\right.$ tonnes $\left.C\right)$. Within the product disposal process, amounts of carbon processed were greatest in landfilling $\left(413 \times 10^{3}\right.$ tonnes $\left.\mathrm{C}\right)$ and the recycling $\left(344 \times 10^{3}\right.$ tonnes $\left.\mathrm{C}\right)$.

\subsection{Sensitivity analyses}

The area of forest and total amount of roundwood harvested produced a 9-10\% change in carbon budgets in the LCI-H sensitivity analysis. The ratio of exported roundwood produced a 5\% change. All other harvest parameters produced less than $2 \%$ change in output (see Fig. 5A).

The LCI-PM parameters varied among mills because of data availability, disclosure and organization of each mill; these differences influenced how the sensitivity analyses were completed. The most significant parameters within the OSB mills were volume of roundwood harvested (9-10\%), total quantity of electricity used (6-7\%) and total quantity of diesel and natural gas used $(1-3 \%)$. All other parameters for the OSB mills produced less than $1 \%$

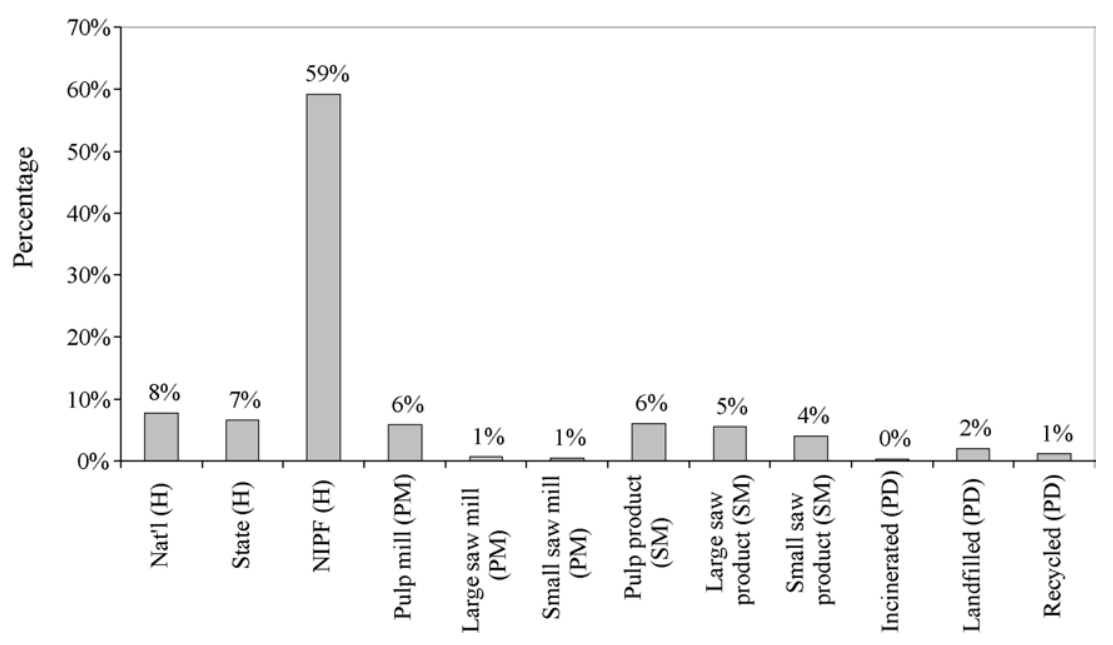

Fig. 4. The percentages that the processes (harvest $(\mathrm{H})$, primary mill (PM), secondary mill (SM), and product disposal (PD)) contribute to the total industrial forest carbon budget calculation. The harvest process $(\mathrm{H})$ has a contributing carbon budget from the national, state, and NIPF; the primary mill process (PM) has a contributing carbon budget from the pulp, large saw, and small saw mills. The pulp mill carbon budgets are assumed to be similar to the pulp (Gower et al., in preparation) and the OSB calculations from objective 2. The large and small saw mill carbon budgets are assumed to be similar to the dimensional lumber mill calculations from objective 2 . The secondary mill process (SM) has a contributing carbon budget assumed to exist from the products produced in the pulp, large, and small saw mills. For example, the secondary mill process includes a carbon budget to represent transportation to a finer product mill, paper processing, furniture assembly, or transportation to a distribution warehouse. The product disposal process (PD), or final fate, has a contributing carbon budget from three end-of-life options, incinerated, landfilled, or recycled. The sum of all percentages equals $100 \%$. 
(A)

Parameter sensitivity of LCI-H

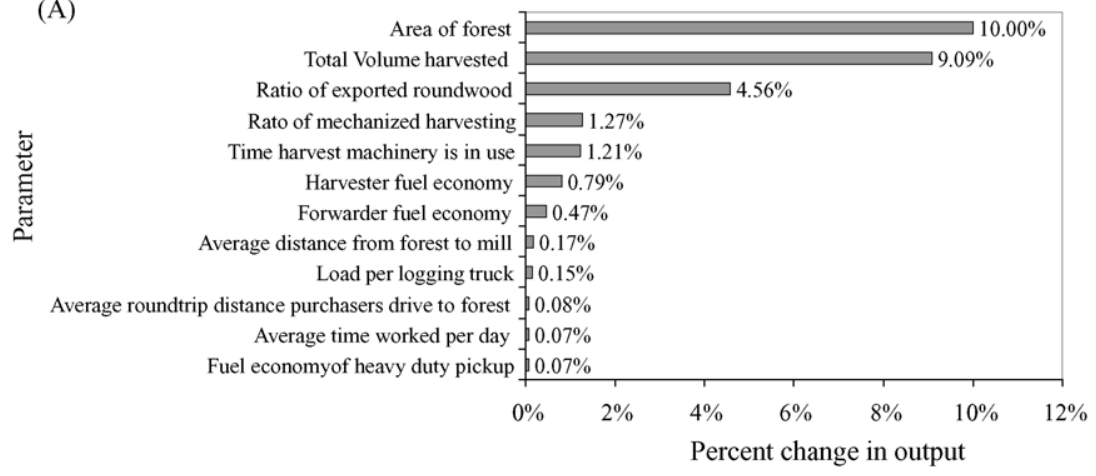

(B)

Parameter sensitivity of LCI-PM for OSB mill A

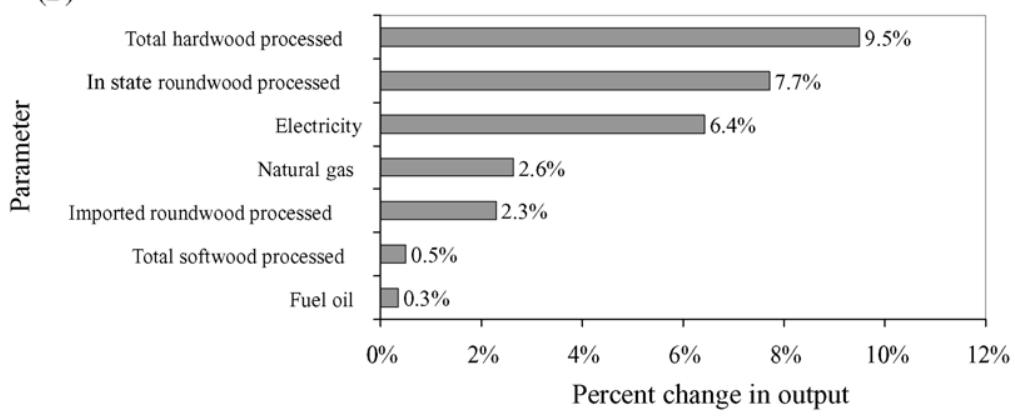

(C)

Parameter sensitivity of LCI-PM for OSB LPT

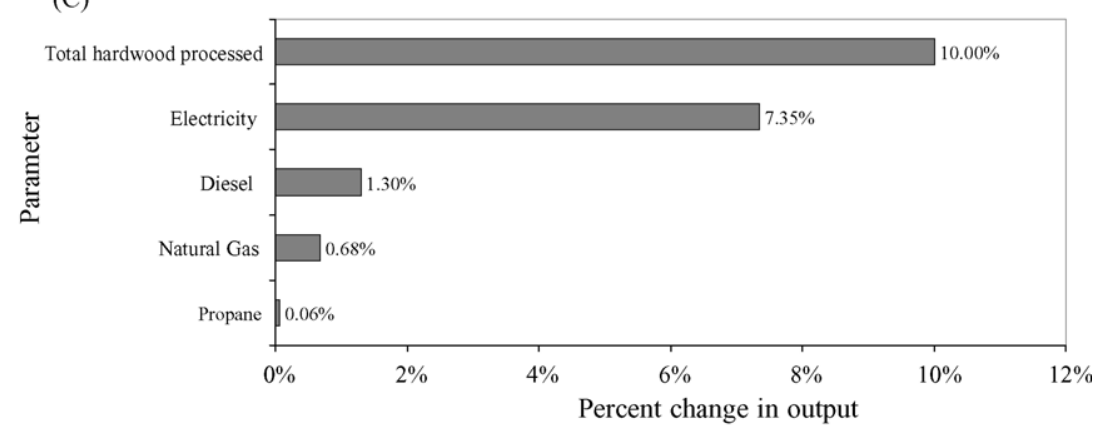

(D)

Paramter sensitivity of LCI-PM for Pukall Lumber

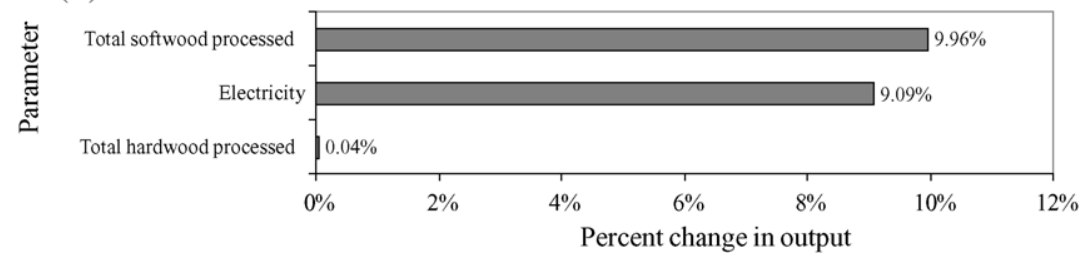

Fig. 5. (A-D) The parameters in the LCI-H and LCI-PM carbon budgets were assessed by calculating the percent change of output when individual parameters were increased by $10 \%$. The higher the percent change of output, the more sensitive the model is to that parameter. 


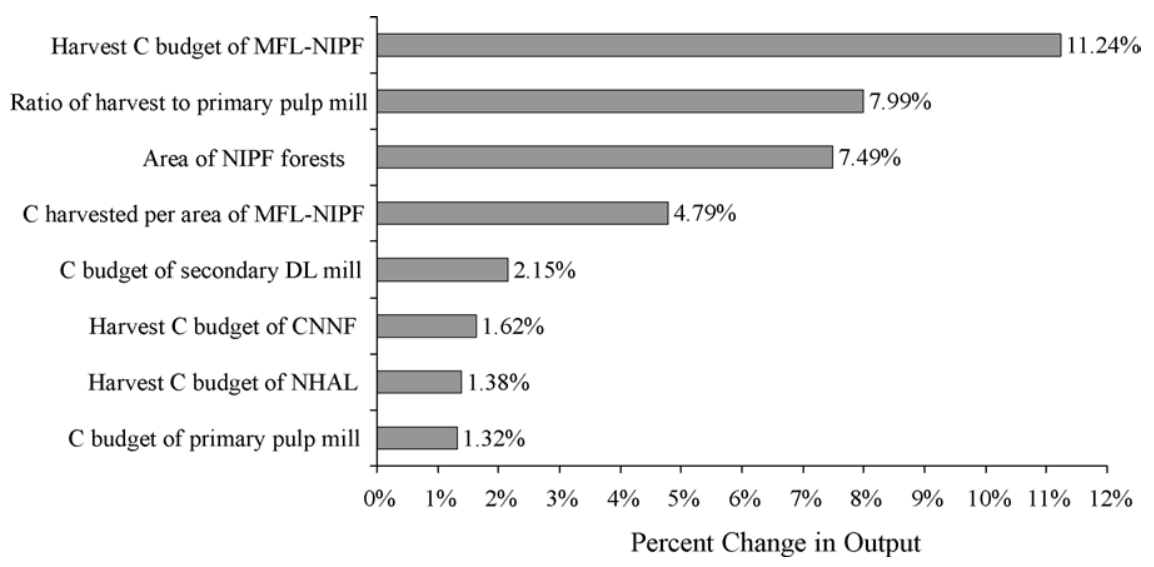

Fig. 6. The eight most sensitive parameters are displayed. The remaining 55 parameters changed output less than $1 \%$.

change in output (Fig. 5B and C). In the dimensional lumber mill volume of roundwood processed $(10 \%)$ and total quantity of electricity used (9\%) had the strongest effect. All other parameters produced less than $0.05 \%$ change in output (Fig. 5D).

Within the industrial forest carbon budget the mass of carbon harvested per area on the MFL-NIPF (11\%), the total area of NIPF in Wisconsin (8\%), the ratio of roundwood that is taken to the pulp primary mill $(8 \%)$ and the carbon budget of the dimensional lumber primary mill process $(2 \%)$ affected model output. All other parameters changed the output by $2 \%$ or less (Fig. 6).

\section{Discussion}

\subsection{The harvest process and forest ownership}

Forest ownership affects the industrial forest system's carbon budget due to the level of mechanization and terrain difficulty (Berg and Karjalainen, 2003) and regional and local factors (Birdsey and Lewis, 2002). In this study, LCI-H carbon budgets differed by as much as $44 \%$, because of harvesting intensity per unit area and ratio of roundwood exports. This is probably because forest management goals (e.g. wildlife, timber, recreation, mature forests, etc.) and economic factors (e.g. nearest buying mill with the best price, need for income by forest owner, etc.) differ. However, LCI-
$\mathrm{H}$ carbon emissions under different forest ownerships were all between -0.08 and -0.09 (tonnes $\mathrm{C}$ emitted/tonnes $\mathrm{C}$ harvested) (Fig. 7). Similarity among carbon emissions per carbon harvested among ownership types is likely because similar ecotypes, terrain and locality produce similar management regimes. For example, the terrain, species, soil and climate composition are similar for the NHAL, CNNF and northern NIPF forests, and therefore the harvest machinery, harvest periods and timber production are similar among the three ownerships. The proximity of all three forest ownerships have similar transportation regimes and local factors and the majority of roundwood harvested in all three forests goes to the nearest buying mills.

Forest ownership directly affects the harvest process, and therefore the industrial forest carbon

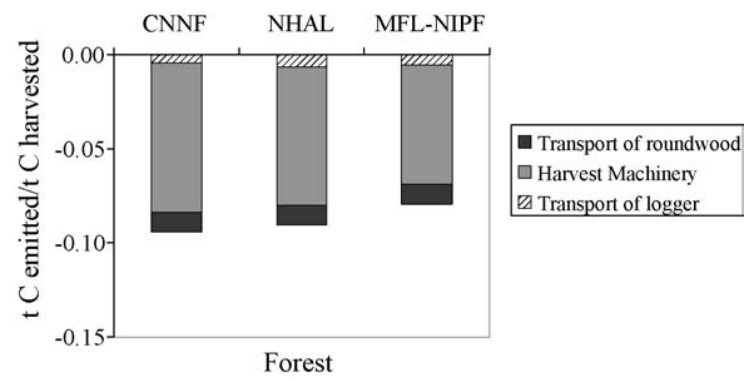

Fig. 7. Forest ownerships were all between -0.08 and -0.09 (tonnes $\mathrm{C}$ emitted/tonnes $\mathrm{C}$ harvested) when normalizing the LCI$\mathrm{H}$ carbon emissions by mass of carbon harvested. 
budget, by controlling how much timber is harvested and which purchaser companies conduct the harvest. This in turn affects harvest intensity and harvest machinery use, which have the potential to produce varying degrees of $\mathrm{CO}_{2}$ emissions.

Industrial forest carbon budgets likely differ within ownership type across the U.S., because state forest policies, purchaser populations, eco-types and terrain differ. For example, if comparisons were made between the national forest analyzed in this study and a National forest located in the Rocky Mountain region of the U.S., differences may occur between harvest policies, terrain, species and distances to primary mills.

Within the industrial forest system, it is important that we understand division of management and how the role each of those divisions can effect carbon sequestration and emission. Under certain policies, for example, it will be important to understand ownership roles, so sequestered carbon credit can be allocated appropriately (Miner and Lucier, 2003). Complete forest product and forest ownership LCI based studies are needed, and they should explicitly define the boundaries of investigation to ensure valid comparisons.

\subsection{The primary mill process and $\mathrm{CO}_{2}$ mitigation opportunities}

Increased energy efficiency in mill processing, and proximity of forest to mill and mill to secondary mill, could decrease $\mathrm{CO}_{2}$ emission and increase carbon sequestration. In this study, similar primary product mills that processed more roundwood tended to be more efficient (in terms of $\mathrm{CO}_{2}$ emissions per carbon processed). Decreases in transportation distances are a more effective means for reducing $\mathrm{CO}_{2}$ emissions than increased transportation fuel economies. Distance becomes very apparent when comparing the expanded LCI-PM results with the Chetwynd dimensional lumber mill analyzed in Gower et al. (in preparation). Most secondary mills or markets of the primary mill products within these case studies are in Wisconsin. There is a large difference when comparing the transportation of primary mill products of the Chetwynd Mill, located in British Columbia, Canada, because the secondary mills or markets are not within the same region. For example, some of the dimen- sional lumber produced from the Chetwynd mill traveled to Wisconsin for secondary processing.

\subsection{Feedback loops}

Feedback loops are movements of pools of carbon that are sequestered or emitted once and are sequestered or emitted two or more times within the same model calculation. Such loops were not incorporated in this study for transparency and clarity within the calculations. Loops exist for offsets of emissions in the land-use change of planting a forest (afforestation), the availability of more land for trees to grow once there is a harvest (reforestation/ regeneration), the carbon offsets of using wood instead of a non-wood products, effects of recycled forest products on supply and demand of virgin forest products, and effects of renewable energy use on consumption of non-renewable energy. Incorporating loops into the model requires analyst valuation of offsets and is more appropriately included in the lifecycle impact assessment and/or simulation stages.

\subsection{An exercise: balancing the industrial and biological forest carbon budgets}

Balancing the forest industrial carbon budget with the forest biological carbon budget is the ultimate aim of a carbon management plan that is sustainable. As an exercise, we calculated the biological carbon budget for the CNNF from aboveground net primary productivity (ANPP) values reported in Fassnacht and Gower (1997) and heterotrophic respiration $\left(R_{\mathrm{H}}\right)$ values reported in Bolstad et al. (2004). By coupling the results from the industrial forest carbon budget for the CNNF, we calculated a range for the 'complete' carbon budget of -897 to $348 \mathrm{~g} \mathrm{C} \mathrm{m}^{-2}$ year $^{-1}$ (Table 6).

This exercise does not warrant a complete analysis, because the boundaries of the forest biological budget do not match those of the forest industrial budget. However, future ecosystem model calculations could hone in on exact boundaries, and successfully couple the two budgets. It is important to note that producing forest products from northern Wisconsin forests could be a viable carbon sequestration activity if the forest biological carbon budget is positive and the industrial forest carbon budget is efficient enough. 
Table 6

Coupled industrial and biological forest carbon budget, an exercise for the CNNF

\begin{tabular}{ll}
\hline Biological carbon budget & \\
$\mathrm{ANPP}^{\mathrm{a}}$ & 290 to 1150 \\
$R_{\mathrm{H}}{ }^{\mathrm{b}}$ & 809 to 1194 \\
$\mathrm{NEP}^{\mathrm{c}}$ & -904 to 341 \\
Industrial carbon budget & 7 \\
LCI $^{\mathrm{d}}$ & \\
Complete carbon budget (CCB) & \\
CCB $^{\mathrm{c}}$ & -897 to 348 \\
\hline
\end{tabular}

Numerical columns display the possible range of values, all in ( $\mathrm{g} \mathrm{C} \mathrm{m}^{-2}$ year $^{-1}$ ).

a Values derived from a woody increment and detritus of 6 stand types in north central Wisconsin (Fassnacht and Gower, 1997).

b Values derived from a northern hardwood and mature aspen stand in Price county in northern Wisconsin from 2001 to 2002 (Bolstad et al., 2004).

${ }^{\mathrm{c}} \mathrm{NEP}=\mathrm{ANPP}-R_{\mathrm{H}}, \mathrm{CCB}=\mathrm{NEP}+\mathrm{LCI}$.

d Industrial forest carbon budget value tabulated from objective 3 results of this study.

\subsection{Implications for carbon trading}

Wood products are sometimes characterized as being either carbon sinks or $\mathrm{CO}_{2}$ neutral (e.g. Skog and Nicholson, 1998). The results from this study point out that if the associated expenditure of fossil fuel and energy are included in the carbon budget analysis, then wood products are carbon sinks. Furthermore, coupling the industrial forest carbon cycle with the biological forest carbon cycle, or the complete forest carbon cycle, has the potential to increase a forest's carbon sink.

\section{Conclusion}

Carbon budget numbers for forest products depend strongly on the methods used to derive them, in part because of environmental, economic and social diversity within the forest product carbon cycle (Matthews, 1996). The question of how representative this study is of other forest ownerships and other forest product chains is difficult to answer because other studies using similar LCI boundaries are lacking.

The LCIs of this study could also serve as inputs into future carbon budget modeling or carbon budget decision support tools which aim to incorporate ecosystem, industry and economy (e.g. GarciaQuijano et al., 2005).

Policies that promote single project objectives for carbon sequestration, such as land acquisition or protection, are not as effective as projects that view forestry holistically (Niles and Schwarze, 2001). If society does in fact decide that project-by-project (PBP) policies are the most effective way to increase carbon sequestration and decrease carbon emissions, then it is imperative that scientists and policy makers continue to incorporate life cycle thinking into their analyses of the carbon cycle associated with forested areas.

\section{Acknowledgements}

The research presented in this publication was funded in whole through the State of Wisconsin Department of Administration, Division of Energy, Focus on Energy Program to S.T. Gower and D.E. Ahl. The authors would also like to thank those that contributed primary data for the purposes of analysis within this study: W. Ruckheim of the U.S. Forest Service, Rhinelander, WI; P.F. Schultz, K. Mather, J.D. Barkley, C.T. Dalton and T. Mace of the Wisconsin Department of Natural Resources; Louisiana Pacific Tomahawk, Louisiana Pacific Hayward, and Pukall Lumber Company; and M. Rickenbach of the University of Wisconsin, Madison.

\section{References}

Apps, M.J., Kurz, W.A., Beukema, S.J., Bhatti, J.S., 1999. Carbon budget of the Canadian forest product sector. Environ. Sci. Policy 2, 25-41.

Athanassiadis, D., Lidestav, G., Nordfjell, T., 2002. Energy use and emissions due to the manufacture of a forwarder. Resour. Conserv. Recy. 34, 149-160.

Berg, S., 1997. Some aspects of LCA in the analysis of forestry operations. J. Cleaner Prod. 5 (3), 211-217.

Berg, S., Karjalainen, T., 2003. Comparison of greenhouse gas emissions from forest operations in Finland and Sweden. Forestry 76 (3), 271-284.

Birdsey, R.A., Lewis, G.M., 2002. Carbon in United States Forests and Wood Products, 1987-1997: State-by-State Estimates. USDA Forest Service, Newtown Square, PA. (http://www.fs.fed. us/ne/global/pubs/books/epa/index.html). Accessed: 1/26/04.

Bolstad, P.V., Davis, K.J., Martin, J., Cook, B.D., Wang, W., 2004. Component and whole-system respiration fluxes in northern deciduous forests. Tree Physiol. 24, 493-504. 
Consoli, F., Allen, D., Boustead, I., Fava, J., Franklin, W., Jensen, A., De Oude, N., Parrish, R., Perriman, R., Postlethewaite, D., Quay, B., Séguin, J., Vigon, B. (Eds.), 1993. Guidelines for Life-Cycle Assessment: A Code of Practice. Society of Environmental Toxicology and Chemistry (SETAC), Pensacola, FL.

Curran, M.A., 1996. Environmental Life-Cycle Assessment. McGraw-Hill, NY.

De Beaufort-Langeveld, A., Bretz, R., Hischier, R., Huijbregts, M., Pascale, J., Tanner, T., Van Hoof, G. (Eds.), 2003. Code of Life-Cycle Inventory Practice. Society of Toxicology and Chemistry (SETAC), Pensacola, FL.

Denison, R.A., 1996. Environmental life-cycle comparisons of recycling, landfilling, and incineration. Ann. Rev. Energy Environ. 21, 191-237.

Department of Agriculture (DOA), 2003. Wisconsin energy statistics. (http://www.doa.state.wi.us/docs_view2.asp?docid=1593) Accessed: 6/11/04.

Evans, D.S., 2000. Terms of the Trade, fourth ed. Random Lengths, Inc., Eugene, OR.

Fassnacht, K.S., Gower, S.T., 1997. Interrelationships among the edaphic and stand characteristics, leaf area index, and aboveground net primary production of upland forest ecosystems in north central Wisconsin. Can. J. For. Res. 27, 10581067.

Forsberg, G., 2000. Biomass energy transport analysis of bioenergy tranport chains using life cycle inventory method. Biomass Bioenergy 19 (1), 17-30.

Garcia-Quijano, J.F., Deckmyn, G., Moons, E., Proost, S., Ceulemans, R., Muys, B., 2005. An integrated decision support framework for the prediction and evaluation of efficiency, environmental impact and total social cost of domestic and international forestry projects for greenhouse gas mitigation: description and case studies. Forest Ecol. Manage. 20, 245262.

Gower, S.T., Mckeon-Ruediger, A., Reitter, A., Bradley, M.J., Taup, A., Tollefson, T., Souba Jr., A.F., Reifkin, J.D., Embury-Williams, B.L., Schiavone, S., Weinbauer, J.D., Janetos, A.C., Johnston, K. Complete greenhouse gas accounting for select forest products: carbon management opportunities. Science, in preparation.

Gower, S.T., 2003. Patterns and mechanisms of the forest carbon cycle. Ann. Rev. Environ. Resour. 28, 169-204.

Intergovernmental Panel on Climate Change (IPCC), 2001. Third assessment report (TAR), climate change 2001: Synthesis report. Cambridge University Press, Cambridge, UK, 2001.

International Standards Organization (ISO), 1998. Environmental Management-Life Cycle Assessment: Goal and Scope Definition and Inventory Analysis. ISO, Geneva, Switzerland.

Karjalainen, T., 1996. Dynamics and potentials of carbon sequestration in managed stands and wood products in Finland under changing climatic conditions. Forest Ecol. Manage. 80, 113132.

Kusko, B.H., Hunt, R.G., 1997. Managing uncertainty in life cycle inventories. Society of Automotive Engineers. Paper No. 970693.

Landsberg, J.J., Gower, S.T., 1997. Applications of Physiological Ecology to Forest Management. Academic, San Diego, CA.
Matthews, R., 1996. The influence of carbon budget methodology on assessments of the impacts of forest management on the carbon balance.. In: Apps, M.J., Price, D.T. (Eds.), Forest Ecosystems, Forest Management and the Global Carbon Cycle, 40, vol. I. NATO ASI Series, pp. 233-243.

Miner, R. The 100-year method for forecasting carbon sequestration in forest products in use. Mitigation and Adaptation Strategies for Global Change. Springer Science and Business Media B.V., in press.

Miner, R.A., Lucier, A.A., 2003. Item 9c: Carbon in harvested wood products. In: FAO Advisory Committee on Paper and Wood Products, 44th Session, Oaxaca, Mexico.

National Association of Fleet Administrators (NAFA), 2004. Energy equivalents of various fuels. (http://www.nafa.org/Content/ NavigationMenu/Resource_Center/Alternative_Fuels/Engergy_ Equivalents/Energy_Equivalents.htm), Accessed: 6/11/04.

Niles, J.O., Schwarze, R., 2001. The value of careful carbon accounting in wood products (edit.) Climatic Change 49, 371-376.

Petersen, A.K., Solberg, B., 2005. Environmental and economic impacts of substitution between wood products and alternative materials: a review of micro-level analyses from Norway and Sweden. Forest Policy Eco. 7, 249-259.

PPI, 1996. International fact and price book. Miller Freeman, Brussels.

Reading IV, W.H., Whipple, J.W., 2003. Wisconsin Timber Industry-an Assessment of Timber Product Output and Use, 1999. USDA FS North Central Research Station, St. Paul, MN.

Rickenbach, M., Steele, T.W. 2003 status of logging in Wisconsin and Michigan's Upper Peninsula. UWEX Cooperative Extension Service. Madison, WI, in preparation.

Schlosser, W.E., Bassman, J.H., Wandschneider, P.R., Everett, R.L., 2003. A carbon balance assessment for containerized Larix gmelinii seedlings in the Russian Far East. Forest Ecol. Manage. 173, 335-351.

Seppala, J., Melanen, M., Jouttijarvi, T., Kauppi, L., Leikola, N., 1998. Forest industry and the environment: a life cycle assessment study from Finland. Resour. Conserv. Recy. 23, 87-105.

Skog, K.E., Nicholson, G.A., 1998. Carbon cycling through wood products: the role of wood and paper products in carbon sequestration. Forest Prod. J. 48, 75-83.

U.S. Environmental Protection Agency (EPA), 2004. Egrid. (www.epa.gov/cleanenergy/egrid/pdfs/state.pdf) Accessed: 6/ $8 / 04$.

Ueda, H., Miyauchi, T., Tsujimura, T., 2003. Application of lifecycle assessment to Shinkansen vehicles and cross ties in Japan. J. Rail Rapid Transit 217, 271-278.

Vitousek, P.M., Mooney, H.A., Lubchenco, J., Melillo, J.M., 1997. Human domination of earth's ecosystems. Science 277, 494 499.

White, M.K., 2005. Life-cycle inventories of roundwood production in Wisconsin-inputs into an industrial forest carbon budget. Master of Science Thesis, University of Wisconsin, Madison, WI.

Winjum, J.K., Brown, S., Schlamadinger, B., 1998. Forest harvests and wood products: sources and sinks of atmospheric carbon dioxide. Forest Sci. 44 (2), 272-284. 
Wisconsin Department of Natural Resources (WDNR), 2003. Recycling facts and figures. PUBL-CE-163, Madison, WI.

World Resources Institute (WRI), World Business Council for Sustainable Development (WBCSD), International Council of
Forest and Paper Associations (ICFPA), and National Council for Air and Stream Improvement (NCASI), 2001. Spreadsheets for calculating GHG emissions from pulp and paper manufacturing, Workbook Version 1.0. 